\title{
PENERAPAN METODE AHP DALAM PROSES PEMILIHAN ALAT ANGKUT BERAT PADA KONSTRUKSI TEROWONGAN LAYANG BAWAH LAUT
}

\section{THE APPLICATION OF AHP METHOD IN THE SELECTION PROCESS OF HEAVY DUTY TRANSPORTER FOR SUBMERGED FLOATING TUNNEL}

\author{
Dwi Agus Purnomo \\ Pusat Teknologi Industri dan Sistem Transportasi \\ Deputi Teknologi Industri Rancang Bangun dan Rekayasa - BPPT \\ Gedung Teknologi 2 BPPT Lantai 3, Kawasan PUSPIPTEK, Tangerang Selatan \\ Telp: 021-75875938; Fax. 021-75875946 \\ e-mail:guspur_btc@yahoo.com
}

\begin{abstract}
Abstrak
Metode Analytic Hierarchy Process (AHP) dikembangkan oleh Thomas L. Saaty pada tahun 1970an. Metode ini adalah merupakan sistem pembuat keputusan dengan menggunakan model matematis. Pemanfaatan dari metode AHP ini akan dapat membantu dalam menentukan prioritas dari beberapa kriteria dengan melakukan analisa perbandingan berpasangan dari masing-masing kriteria. Dalam sistem pengelolaan kinerja yang dimaksud dengan kriteria tersebut, yang selanjutnya disebut Kinerja Pengelolaan Indikator (KPI). Penerapan metode AHP dalam proses pemilihan alat angkut berat diaplikasikan pada proyek pembangunan terowongan layang bawah laut di Kepulauan Seribu dengan mengidentifikasi atribut kriteria dan alternatif untuk, menentukan besar prioritas atribut dan alternative. Proses analisis melalui pendekatan AHP dengan atribut kriteria- Level 1 dan alternatif-Level 2 terhadap tujuan-Level 0; maka dipilih jenis alat angkut berat sebagai alternatif dengan unsur kriteria tertentu.
\end{abstract}

Kata kunci : AHP, Konstruksi Terowongan Layang Bawah Laut

\begin{abstract}
Analytic Hierarchy Processherein after referred as AHP is a method that has developed by Thomas L. Saaty in year 1970. This method is likely a decision making system within using mathematic model. Utilization of AHP method that can help people to decide several criteria priority by pare analysis of each criteria. In managing system of performance mentioned with these criteria that can referred as Indicator Management Performance. Application of AHP method in processing of heavy equipment selection will be applied in submerged floating tunnel construction project at Kepulauan Seribu by identify criteria attribute and alternative to decide priority vector of these attribute and alternative. Analyzing process thorough AHP nearby within attribute criteria-Level1 and alternative criteria-Level2 face to objective criteria-Level 0, therefore it can be selected the heavy equipment as the alternative with the element criteria.
\end{abstract}

Key words : AHP, Submerged Floating Tunnel Construction.

Diterima (received) : 19 Juni 2013, Direvisi (reviewed) : 22 Juni 2013,

Disetujui (accepted) : 12 Juli 2013 


\section{PENDAHULUAN \\ Peran AHP dalam proses pemilihan alat angkut berat}

Pada aplikasi pemilihan peralatan konstruksi terowongan layang bawah laut (Submerged Floating Tunnel-SFT), maka metode AHP dari L. Saaty ${ }^{3)}$ dalam bukunya "The Analytic Hierarchy Process" dapat dimanfaatkan dan berperan untuk membantu menganalisa pemilihan alat angkut berat pada pemasangan badan SFT yang berbentuk pipa U.

Rencana pembangunan konstruksi SFT yang berada diantara Pulau Karya dan Pulau Panggang Kepulauan Seribu seperti pada Gambar 1, akan mengalami pasang surut dan angin kencang, adalah menjadi pertimbangan penting mengapa diperlukan pemilihan alat angkut berat tertentu dalam metode pelaksanaan pemasangan badan SFT yang memadai. Selain itu, keterbatasan waktu dan biaya juga merupakan faktor penyebab pekerjaan pemasangan badan terowongan layang bawah laut juga merupakan faktor penyebab pekerjaan pemasangan tersebut menjadi hal yang sangat penting dalam kegiatan Manajemen Konstruksi seperti yang diutarakan ${ }^{5}$.

\section{Penggunaan metode AHP dalam sistem pengelolaan kinerja}

Kaidah pembobotan dinyatakan sebagai berikut :

1. Nilai bobot KPI berkisar antara $0-1$ atau antara $0 \%-100 \%$ jika kita menggunakan prosentase.

2. Jumlah total bobot semua KPI harus bernilai 1 (100\%)

3. Tidak ada bobot yang bernilai negatif (-).

\section{BAHAN DAN METODE}

\section{Menentukan nilai prioritas KPI}

Biasanya orang lebih mudah mengatakan bahwa KPI A lebih penting dari pada KPI B, $\mathrm{KPI} B$ kurang penting dibanding dengan $\mathrm{KPI}$ C dsb, namun mengalami kesulitan menyebutkan seberapa penting KPI A dibandingkan KPI B atau seberapa kurang pentingnya $\mathrm{KPI} \mathrm{B}$ dibandingkan dengan $\mathrm{KPI}$ C.

Untuk itu kita perlu membuat tabel konversi dari pernyatan prioritas ke dalam angka-angka. Contoh tabel skala nilai prioritas KPI seperti pada Tabel 1.

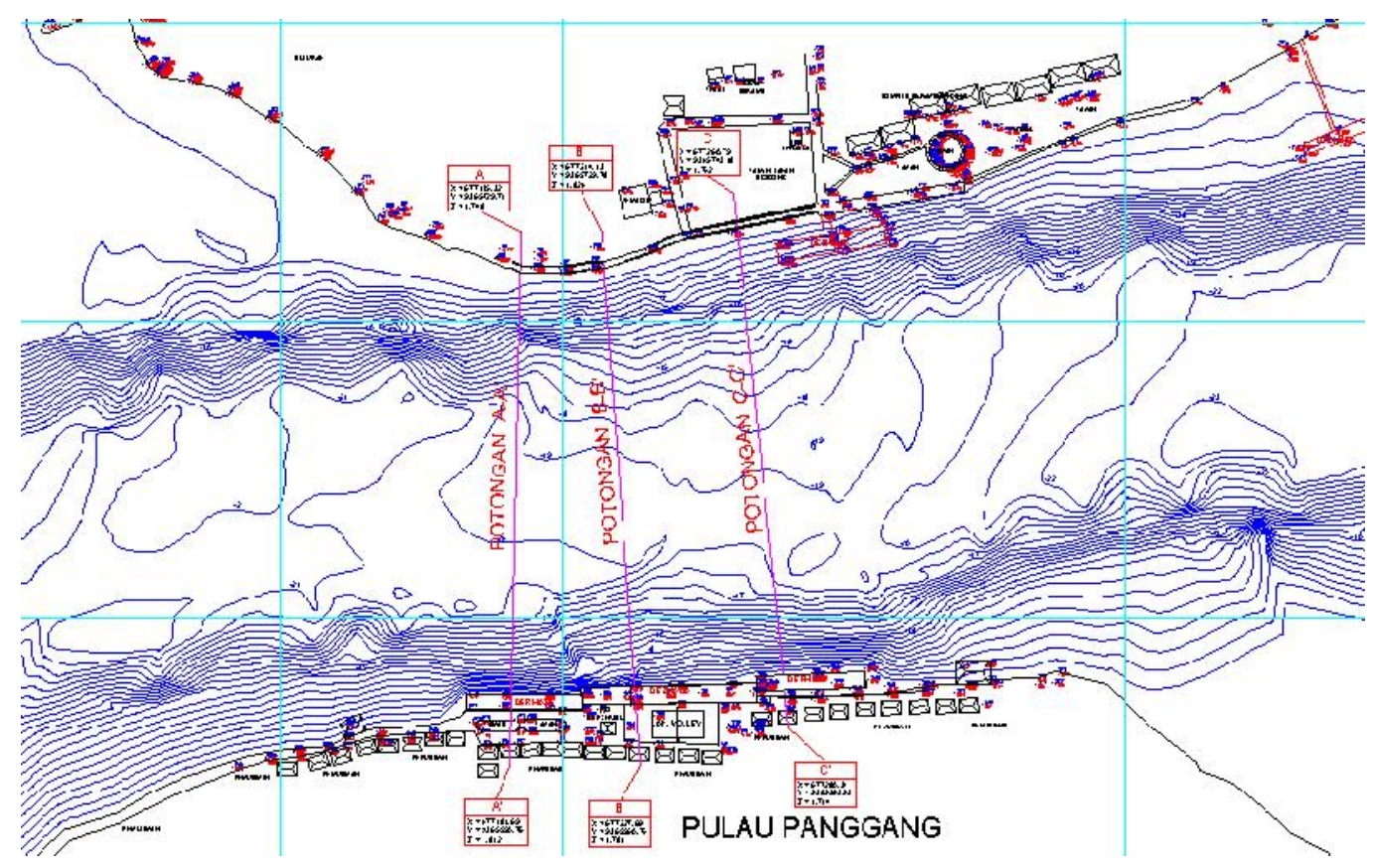

Gambar 1

Layout Rencana Lokasi Penyeberangan 


\begin{tabular}{|c|c|}
\hline \multicolumn{2}{|c|}{$\begin{array}{c}\text { Tabel 1 } \\
\text { Nilai KPI }\end{array}$} \\
\hline Nilai & Tingkat prioritas \\
\hline 1 & $\begin{array}{l}\text { KPI A sama penting dibanding dengan KPI } \\
\text { B }\end{array}$ \\
\hline 3 & $\begin{array}{l}\text { KPI A sedikit lebih penting dibanding } \\
\text { dengan KPI B }\end{array}$ \\
\hline 5 & KPI A lebih penting dibanding dengan KPI B \\
\hline 7 & $\begin{array}{l}\text { KPI A sangat penting dibanding dengan KPI } \\
\text { B }\end{array}$ \\
\hline 9 & $\begin{array}{l}\text { KPI A jauh sangat penting dibanding } \\
\text { dengan KPI B }\end{array}$ \\
\hline \multicolumn{2}{|c|}{$2,4,6,8$ *) nilai tengah-tengah } \\
\hline$\left.{ }^{*}\right)$ & $\begin{array}{l}\text { Pengertian nilai tengah-tengah adalah } \\
\text { Jika KPI A sedikit lebih penting dari KPI B } \\
\text { maka kita seharusnya memberikan nilai } \\
\text { 3, namun jika nilai } 3 \text { tersebut dianggap } \\
\text { masih terlalu besar dan nilai } 1 \text { masih } \\
\text { terlalu kecil maka nilai } 2 \text { yang harus kita } \\
\text { berikan untuk prioritas antara KPI A } \\
\text { dengan KPIB. }\end{array}$ \\
\hline & $\begin{array}{l}\text { Tabel } 1 \text { tidak disebutkan konversi nilai } \\
\text { KPI A kurang penting dari KPI B karena } \\
\text { pernyataan KPI A kurang penting dari } \\
\text { KPI B sama dengan pernyataan nilai KPI } \\
B \text { lebih penting dari KPI A }\end{array}$ \\
\hline
\end{tabular}

\section{Pembuat Tabel Perbandingan Prioritas Setiap KPI}

Proses dalam tahap ini adalah membuat table perbandingan prioritas setiap KPI dengan membandingkan masing-masing $\mathrm{KPI}$. Sebagai contoh: Jika kita mempunyai $4 \mathrm{KPI}$, maka kita membuat matrik perbandingan ke$4 \mathrm{KPI}$ tersebut. Misalkan dari proses membandingkan antar KPI diperoleh nilai prioritas KPI seperti pada Tabel 2.

Tabel 2

Nilai perbandingan KPI dengan prioritas ${ }^{1)}$

\begin{tabular}{lcc|c|c|c}
\hline & KPI A & \multicolumn{1}{c}{ KPI B } & \multicolumn{1}{c}{ KPI C } & \multicolumn{1}{c}{ KPI D } \\
\hline KPI A & 1 & $1 / 2$ & $1 / 5$ & $1 / 3$ \\
\hline KPI B & 2 & 1 & $1 / 3$ & 1 \\
\hline KPI C & 5 & 3 & 1 & $1 / 2$ \\
\hline KPI D & 3 & 1 & 2 & 1 \\
\hline
\end{tabular}

Cara mengisinya adalah dengan menganalisa prioritas antara $\mathrm{KPI}$ baris dibandingkan dengan KPI kolom. Dalam prakteknya kita hanya perlu menganalisa prioritas KPI yang terdapat dibawah pada garis diagonal (kotak dengan warna dasar putih) yang ditunjukan dengan warna kuning atau diatas garis diagonal yang ditunjukan dengan kotak warna hijau. Hal ini sesuai dengan persamaan matematika yang menyebutkan jika $A: B=X$, maka $B: A=1 / X$.
Contoh: jika prioritas KPI B (baris) : KPI A $($ kolom $)=2$, maka prioritas KPI A (baris) : KPI $\mathrm{B}(\mathrm{kolom})=1 / 2$ (lihat rumus persamaan perbandingan matematika diatas). Sehingga prioritas setiap $\mathrm{KPI}$ antara $\mathrm{KPI} A$ : $\mathrm{KPI} A=1$, $\mathrm{KPI} C: \mathrm{KPI} A=5, \mathrm{KPI} C: \mathrm{KPI} B=3, \mathrm{KPI} D$ : $\mathrm{KPI} A=3, \mathrm{KPI} D: K P I B=1, K P I D: K P I C=$ 2.

\section{Menentukan Bobot Pada Setiap Elemen KPI.}

Proses dalam tahap ini adalah menentukan bobot pada tiap KPI, nilai bobot ini berkisar antara $0-1$. dan total bobot untuk setiap kolom adalah 1. Cara menghitung bobot adalah angka pada setiap kotak dibagi dengan penjumlahan semua angka dalam kolom yang sama. Contoh bobot dari $(\mathrm{KPI} A, \mathrm{KPI} A)=1 /(1+2+5+3)=$ 0.091, $(\mathrm{KPI} B, \mathrm{KPI} A)=2 /(1+2+5+3)=$ 0.181 . Dengan perhitungan yang sama bobot prioritas Tabel 2 tersebut menjadi seperti pada Tabel 3:

Tabel 3

Bobot setiap elemen $\mathrm{KPI}^{1)}$

\begin{tabular}{lllll}
\hline & KPI A & KPI B & KPI C & KPI D \\
\hline KPI A & 0.091 & 0.091 & 0.057 & 0.118 \\
KPI B & 0.182 & 0.182 & 0.094 & 0.353 \\
KPI C & 0.455 & 0.545 & 0.283 & 0.176 \\
KPI D & 0.273 & 0.182 & 0.566 & 0.353 \\
\hline
\end{tabular}

Selanjutnya adalah mencari nilai bobot untuk masing-masing KPI. Caranya adalah dengan melakukan penjumlahan setiap nilai bobot prioritas pada setiap baris tabel dibagi dengan jumlah KPI. Sehingga diperoleh bobot masing-masing KPI adalah:
a. $\mathrm{KPI} A=(0.091+0.091+0.057+0.118) /$ $4=0.089(8.9 \%)$
b. $\mathrm{KPI} B=(0.182+0.182+0.094+0.353) /$ $4=0.203(20.3 \%)$, dengan perhitungan yang sama KPI C, KPI D
c. $\mathrm{KPIC}=0.365(36.5 \%)$
d. $K P I D=0.343(34.3 \%)$

Sehingga jumlah total bobot semua $\mathrm{KPI}=$ $1(100 \%)$ sesuai dengan kaidah pembobotan dimana jumlah total bobot harus bernilai 100 . Perhitungan secara manual akan lebih mudah jika jumlah KPI yang dimiliki hanya sedikit, jika jumlah KPI sudah lebih dari 10 maka perhitungan bobot menggunakan software akan jauh lebih mudah. Ada beberapa software yang bisa dipakai antara lain Expert Choice, Decision Lens, TESS, Web-HIPPRE. ${ }^{3)}$

Proses yang paling menentukan dalam menentukan bobot KPI dengan 
menggunakan AHP adalah menentukan besarnya prioritas antar KPI. Karena itu seringkali terjadi pembahasan yang alot antar anggota tim implementasi sistem pengelolaan kinerja mengenai masalah tersebut. Hal ini dikarenakan tiap-tiap anggota tim memiliki persepsi tersendiri mengenai prioritas masing-masing KPI.

\section{HASIL DAN PEMBAHASAN Umum}

Khusus untuk aplikasi dalam pemilihan peralatan konstruksi $S F T$, metode AHP dimanfaatkan untuk membantu menganalisa pemilihan peralatan untuk pemasangan (erection) badan SFT yang berbentuk Pipa U.

Pembangunan konstruksi SFT yang berada diantara Pulau Karya dan Pulau Panggang Kepulauan Seribu (Gambar 1), akan mengalami pasang surut dan angin kencang, adalah menjadi pertimbangan penting mengapa diperlukan pemilihan metode pelaksanaan pemasangan badan $S F T$ yang memadai. Selain itu, keterbatasan waktu dan biaya juga merupakan faktor penyebab pekerjaan erection badan $S F T$ juga merupakan faktor penyebab pekerjaan erection tersebut menjadi hal yang sangat penting.

Dari permasalahan tersebut, maka perlu dikaji metode apa yang cocok pada pekerjaan pemasangan) badan terowongan layang bawah laut, dengan menggunakan Analisis Hierarki Proses (AHP) berdasarkan kelompok KPI mutu, waktu, biaya, cara operasi dan resiko, dengan 3 alternatif metode pelaksanaan yaitu metode Floating Cranes, metode Turn Roll dan rail - scradel system yang dimodifikasi dengan roda besi, metode Kura-Kura yang dikombinsasi dengan winch roller.

Berdasarkan kajian kriteria dan metode pelaksanaan tersebut, maka dapat digambarkan proses hirarkhi (hierarchy process) dalam menetapkan bobot prioritas (priority vector) yang dibagi dalam Level 0 : Fokus, Level 1 : KPI/Kriteria, dan Level 2 : Alternatif, seperti pada Gambar $2^{2)}$

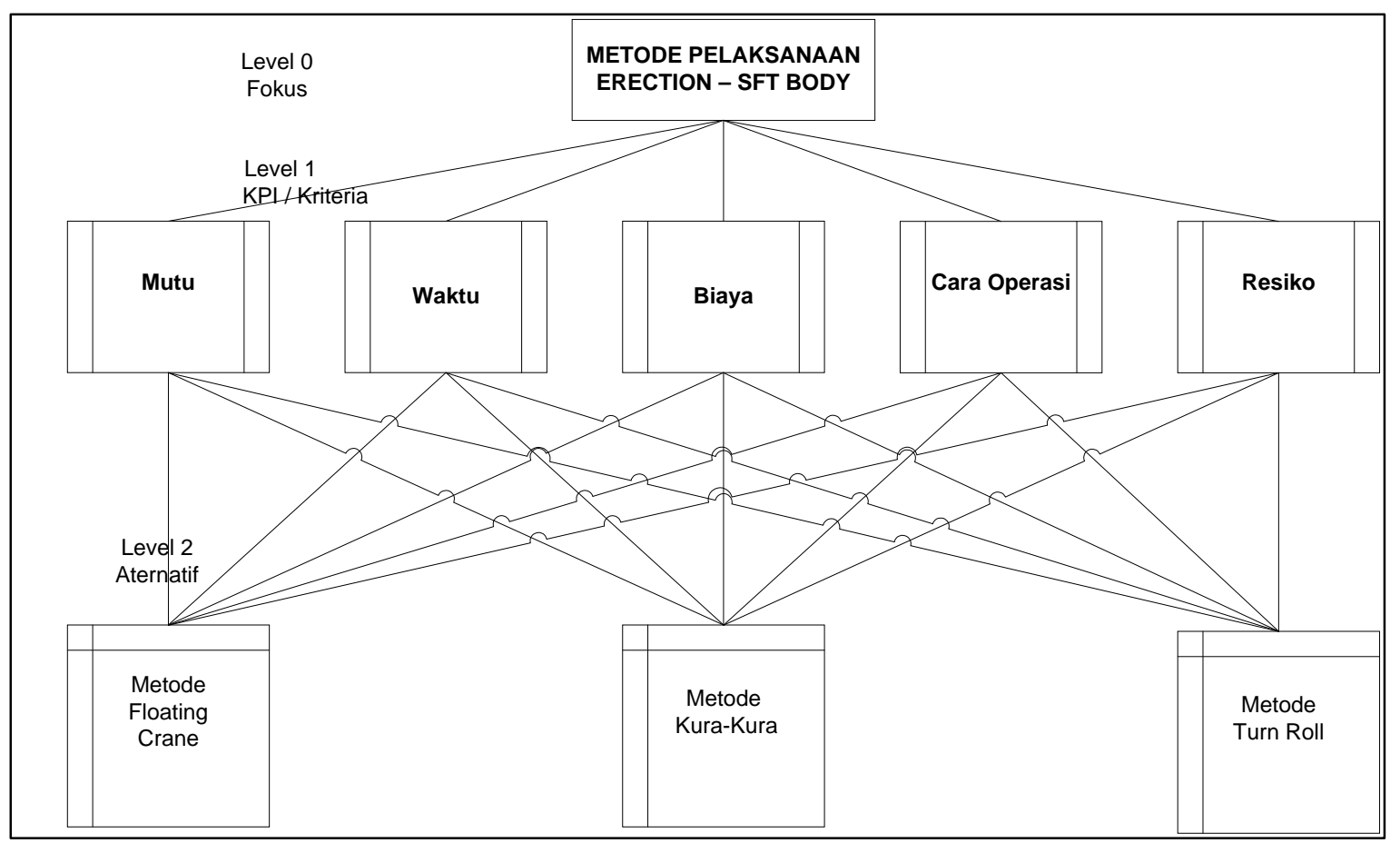

Gambar 2. ${ }^{2)}$

Bagan Bobot Prioritas Setiap Elemen Hierarkhi 


\section{Alternatif metode konstruksi (bobot prioritas Leve 2) dan KPI Pendukung (bobot priotitas Level 1)}

Bobot Prioritas pada elemen Level 2 yang disebut alternatif metode konstruksi, dalam pembangunan terowongan layang bawah laut (SFT) khususnya untuk pemasangan badan SFT dipilih 3 alternatif metode konstruksi menurut Wilopo ${ }^{2)}$ dijabarkan untuk masingmasing alternatif metode konstruksi tersebut adalah sebagai :

\section{a. Metode Floating Crane}

Pada metode ini digunakan 2 unit floating cranes berkapasitas 100 Ton untuk meletakan badan SFT pada abutment, Floating crane tersebut ditempatkan diatas ponton. Untuk menjaga kestabilan, maka floating crane dikaramkan dengan cara diisi air pada bagian pontonfoating crane (air balas). Mobilisasi badan SFT dilaut menggunakan ponton ditarik dengan tug boat yang dikapalkan dari tempat fabrikasi, dan setelah sampai dilokasi penempatan SFT.Badan SFT yang diangkut dalam bentuk segmen-segmendisambung terlebih dahulu diatas ponton tersebut atau dengan pontonlain sehingga siap untuk dipasang (erected). Untuk memindahlan badanSFT dari ponton angkut sampai floating crane, menggunakan 2 unit crane kapasitas 100 Ton (berat body SFT 150 Ton).

\section{b. Metode Kura-Kura}

Metode ini hampir sama dengan metode floating crane, yang berbeda hanya pada saat alat berat yang digunakan untuk melaksanakan pemasangan badan SFT. Metode ini digunakan 2 unit crawaler crane berkapasitas 100 Ton untuk meletakan badan SFT pada abutment. Crawler crane ditempatkan di atas ponton. Untuk menjaga kestabilan crawler crane maka ponton dikaramkan dengan cara diisi air pada bagian badan poton. Mobilisasi badan SFT dilaut mengggunakan ponton angkut yang dikapalkan dari tempat fabrikasi dalam bentuk segmen-segmen dan setelah sampai di lokasi penempatan, segmen-segmen badan SFT disambung didaratan yang kemudian diangkut dengan roller bogie yang ditarik dengan winches secara manual menuju bearing pad. Untuk menentukan kestabilan crawler maka dibantu dengan ponton sebagai dudukannya. Untuk memindahkan badan SFT dari roller bogie ke bearing pad, digunakan 2 unit crane berkapasitas masing-masing 100 Ton yang mengangkat material secara bersamaan.

\section{c. Metode Turn Roll}

Metode ini menggunakan semacam bogie beroda besi dengan rel yang diletakan di darat yang di dukung dengan crawler crane kapaitas 100 Ton pada kedua ujung abutment. Mobilisasi badan SFT didarat menggunakan Turn Roll (scradel beroda besi) dan mobilisasi dilaut menggunakan peluncur rel dimana badan SFT dapat diapungkan dengan ditutup pada kedua ujung badan SFT. Untuk memindahkan badan SFT yang terapung, digunakan 2 unit crawler crane kapasitas masing-masing 100 ton yang mengangkat material secara bersamaan.

\section{Analisa dari elemen Level 2: Alternatif terhadap elemen Level 1: KPI}

Menurut Dipohusodo ${ }^{1)}$ dan Ervanto ${ }^{5)}$, dalam kegiatan manajemen proyek dan konstruksi secara umum akan terfokus pada hal "biaya-mutu-waktu". Dengan demikian, maka dalam pengelolaan KPI akan mencakup hal tersebut dan durasi pemasangan badan SFT berdasarkan metode konstruksi dapat ditunjukkan pada Tabel 4.

Analisa diagram dimulai dari analisis permasalahan pada elemen Level 2 : Alternatif yang dipilih untuk dapat dilakukan pembobotan pada elemen Level 1 : $\mathrm{KPI} /$ Kriteria yang dilanjutkan untuk dapat menentukan Prioritas Vector (bobot prioritas) pada elemen Level 2: Alternatif (Floating Crane, Kura-Kura, Turn Roll) dan elemen Level 1: KPI, dimana masing-masing KPI akan mempunyai elemen dengan rincian sebagai berikut :

1. KPI Mutu, mempunyai elemen :

1) Faktor penurunan mutu Badan $S F T$

2) Kepresisian Penempatan Badan SFT pada Bearing Pad (dudukan).

2. KPI Waktu, mempunyai elemen :

1) Cycle time/body SFT

2) Produktifitas (body $S F T / / j a m$ )

3) Durasi / body SFT

4) Durasi / bentang

3. KPI Biaya, mempunyai elemen :

1) Biaya pemilikan

2) Biaya bahan bakar

3) Biaya pelumas

4) Biaya pemeliharaan alat

5) Biaya operator.

4. KPI Cara Operasi, mempuyai elemen :

1) Mobiliasi ke proyek

2) Tumpuan

3) Pengaruh kondisi permukaan 

4) Cara men-stabil-kan alat
5) Pergerakan alat untuk Erection.

5. KPI Resiko, mempunyai elemen :

1) Pemindahan segmen $S F T$ dari stock area ke atas bogie truck

2) Mobilisasi material $S F T$ menuju pelabuhan

3) Material SFT dipindahkan ke atas ponton

4) Ponton ditarik menggunakan Tug Boat

5) Body SFT dirakit di daratan dan dipindahkan ke atas Abutment

6) Meletakan As Body SFT sesuai dengan as Bearing Pad.

6. Prioritas Vector pada Level2 : Alternatif, mempunya elemen :
1) Metode Floating Crane
2) Metode Kura-Kura
3) Metode Turn Roll.

Dari analisa elemen Level 2: Alternatif diperoleh nilai perbandingan antar elemen dalam Level 2: KPI yang dapat ditunjukkan dalam contoh elemen KPI: Waktu seperti pada Tabel 4.
Dari hasil analisa KPI: Waktu pada level 1 terhadap masing-masing Alternatif pada level 2 dengan memasukan bobot kriteria, maka diperoleh Nilai Normal seperti pada Gambar 3.

Kemudian, dari hasil analisi gradient dan nilai baru terkonversi, selanjunya dapat diperoleh Nilai Normal Baru masing-masing alternatif dengan menjumlahkan nilai baru terkonversi dibagi jumlah seluruh nilai terkoversi, seperti pada Gambar 4.

Dari hasil analisa nilai normal pada Gambar 3. Selanjutnya dapat dianalisis Nilai Baru Terkonversi berdasarkan "kisaran data" dari nilai lama (old lower bond) dan oub (old upper bond), dengan memasukan nilai nlb (new lower bond) $=0$ dan nub (new upper bond) $=1$, diperoleh:

- $\quad$ gradient $=($ nub-nlb) $/($ oub-olb $)+$ $n / b$

- $\quad$ nilai baru terkonversi $=$ gradient ${ }^{*}$ (bobot kriteria-olb) .

Tabel 4.

Perbandingan Durasi Pemasangan Badan SFT dari Elemen KPI: Waktu

\begin{tabular}{llcccc}
\hline No & Metode & $\begin{array}{c}\text { Cycle Time/body SFT } \\
\text { (menit) }\end{array}$ & $\begin{array}{c}\text { Produk tifitas } \\
\text { Q (body } \\
\text { SFT/jam) }\end{array}$ & $\begin{array}{c}\text { Durasi// } \\
\text { body SFT } \\
\text { (jam) }\end{array}$ & $\begin{array}{c}\text { Durasi/ } \\
\text { bentang } \\
\text { (hari) }\end{array}$ \\
\hline 1 & Floating Crane & 270 & 0,17 & 5.88 & 0.98 \\
2 & Kura-Kura & 375 & 0.12 & 8.33 & 1.39 \\
3 & Turn Roll & 240 & 0,19 & 5.26 & 0.87 \\
\hline
\end{tabular}

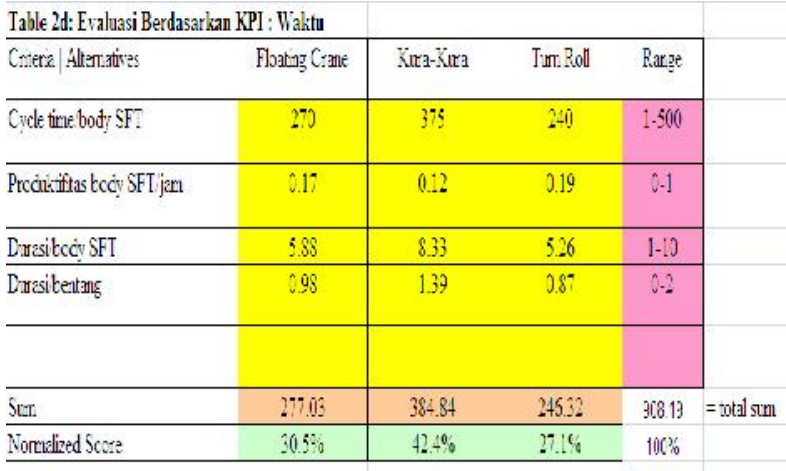

Gambar 3.

Hasil Analisis Nilai Normal dari KPI: Waktu.

\begin{tabular}{|c|c|c|c|c|c|c|}
\hline \multicolumn{7}{|l|}{ Original Scores IKPI: woktul } \\
\hline Crseria | Nernabives & Aloring Lirne & Kra Sura & Im Rol & $a b$ & dic & zajex: \\
\hline Cycle tue / body SF: & 270 & 375 & 240 & 1 & $500^{\circ}$ & $x$ \\
\hline Produkifiles buis SET:Cu & i.1.1? & 0.12 & 0.19 & 0 & $!$ & \% \\
\hline Duras cody \&F: & 5.88 & 833 & 526 & 1 & 10 & 3.11 \\
\hline Durasterang & 0.98 & 139 & 0.87 & 0 & 2 & TfC \\
\hline & \multicolumn{2}{|l|}{ Itw was } & \multicolumn{2}{|c|}{ j } & & \\
\hline & 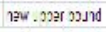 & & & & & \\
\hline \multicolumn{7}{|c|}{ Ialble 4d: Cuaverled Sev Scores kased un Rague (KPI: wakiu) } \\
\hline Crisena A Aternatives & \multicolumn{2}{|c|}{ - Toring Crant Kax-Zure. } & \multicolumn{2}{|l|}{ Twa:ใด] } & & \\
\hline Code tac badr SF: & $0.530_{0}^{7} 81.56$ & 0.140498258 & $0.4789599 ! 6$ & & & \\
\hline Produktifls bods SET:m & 0.17 & 0.12 & 0.19 & & & \\
\hline Duras body s:1 & $0.5+2.21212$ & 0.814444444 & (1.473j3j33j & & & \\
\hline 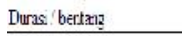 & $0 .-9$ & 0.65 & 0.435 & & & \\
\hline Surr. & $1.7 !$ & 2.379 & 1.577 & 5698 & $=$ total sur. & \\
\hline Nonutei Sun: & $30.6 \%$ & $41.8 \%$ & $27 \% 8$ & 10006 & & \\
\hline
\end{tabular}

Gambar 4.

Nilai Normal Baru Terkonversi Untuk KPI:Waktu 

(Dwi Agus Purnomo)

Selanjutnya dilakukan analisis terhadap pembobotan tingkat kepentingan dari KPI : Waktu, sehingga akan diperoleh prosentase bobot kepentingan dari masing-masing elemen KPI seperti pada Gambar 5

\begin{tabular}{|c|c|c|c|c|c|}
\hline & \multicolumn{3}{|c|}{ Toble sos: Weight of lmpottance ||KP): :Waktu| } & & \\
\hline & Sistena Wist & tera Wattı & Kravia Wiath & Fitreni Wiat & \\
\hline 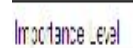 & 9 & 7 & 5 & $\hat{\vdots}$ & 27 \\
\hline 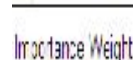 & $395 \%$ & $25 \%$ & $20.8 \%$ & $25 \%$ & $10 \% \%$ \\
\hline
\end{tabular}

HeE:

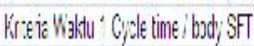

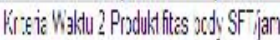

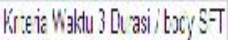

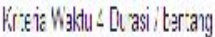

Gambar 5.

Prosentase Bobot Kepentingan untuk KPI : Waktu

Dari hasil Nilai Terkonversi pada Gambar 4 dan Prosentase Bobot Kepentingan pada Gambar 5, selanjutnya dilakukan analisis terhadap Nilai Bobot baru dari masing-masing kriteria KPI dan Nilai Normalnya dengan cara mengalikan. Dengan demikian akan didapat nilai seperti pada Gambar 6 .

\begin{tabular}{|c|c|c|c|c|c|}
\hline \multicolumn{5}{|c|}{ 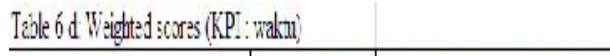 } & \\
\hline 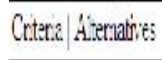 & Wiglght & Finteg Crace & Kira:Kraza & TruRoll & \\
\hline Zitrena Wakn! & $33: 5$ & $0.20 ?$ & 0.81 & 0.180 & \\
\hline Znjtenia Wakn? & $202 \%$ & 0.050 & 0.335 & 0.655 & \\
\hline Zitrenia Wakn? & $20.8 \%$ & 0.113 & $0.17)$ & 0.699 & \\
\hline Kritenia Wakul & $15.5 \%$ & $0.6{ }^{6} 1$ & 0.087 & 0.64 & \\
\hline Stas & $100 \%$ & 0.426 & 0.573 & 0388 & $1387=601 \mathrm{~d}$ \\
\hline Voralibec Score & & $30.9 \%$ & $4.3 \%$ & $2819 \%$ & $100 \%$ \\
\hline
\end{tabular}

Kiteia Wisti: Cycle ine 'tedy SFI

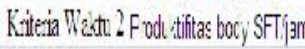

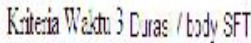

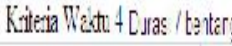

Gambar 6.

Nilai Bobot Terkonversi dan Nilai Normal untuk KPI : Waktu

\section{Analisis terhadap Perhitungan AHP- "Matrix 3×3".}

Cara mengisinya adalah dengan menganalisa prioritas antara $\mathrm{KPI}$ baris dibandingkan dengan KPI kolom dari hasil analisis pada Gambar 4. Dalam prakteknya, hal ini hanya perlu menganalisa prioritas KPI yang terdapat di bawah pada garis diagonal (kotak dengan warna dasar putih) yang ditunjukkan dengan warna kuning atau di atas garis diagonal yang ditunjukan dengan kotak warna hijau. Hal ini sesuai dengan persamaan matematika yang menyebutkan

$$
\text { jika } A: B=X \text {, maka } B: A=1 / X \text {. }
$$

Dari hasil analisis "Matrix $3 \times 3$ " dengan data dari Nilai Bobot Terkonversi pada Gambar 4, selanjutnya dapat dianalisis Matrix Normal dan Vektor Prioritas (Priority Vector), dimana nilai valid dari Priority Vector tersebut diperoleh apabila diperoleh nilai $C R$ (Consistency Ratio) < $1 \%$ dari hasil analisis. Adapun formula yang dipakai adalah sebagai berikut :

$$
\mathrm{CR}=\mathrm{Cl} / \mathrm{RI}
$$

dimana;

$\lambda \max =\left(\sum_{*}\right.$ Reciprocal Matrix Alt.KPI

$\mathrm{Cl}=(\lambda-n) /(n-1)$

$\mathrm{n}=$ ukuran matrix simetris, misal Matrik ukuran $3 \times 3$ maka $n=3$.

$R I=$ Random Consistency Index, sesuai Tabel 8 berikut:

Tabel 8

Random Consistency Index (R1)

\begin{tabular}{cc}
\hline $\mathbf{n}$ & $\mathbf{R 1}$ \\
\hline 1 & 0.00 \\
2 & 0.00 \\
3 & 0.58 \\
4 & 0.90 \\
5 & 1.12 \\
6 & 1.24 \\
7 & 1.32 \\
8 & 1.41 \\
9 & 1.45 \\
10 & 1.49 \\
11 & 1.51 \\
12 & 1.48 \\
13 & 1.56 \\
14 & 1.57 \\
15 & 1.59 \\
\hline
\end{tabular}




\section{Analisis Terhadap Elemen Hierarkhi Pada Metode Kontruksi SFT}

Hasil analisis terhadap Priority Vector masing-masing alternatif untuk KPI : Watu dapat dilihat pada Gambar 7. Dengan cara analisis yang sama, maka akan diperoleh hasil analisis Priority Vector ${ }^{4}$ masing-masing Alternatif untuk semua jenis KPI : (mutu, biaya, cara operasi, dan resiko) seperti pada Gambar 8 s.d. Gambar 11. Dengan merata-

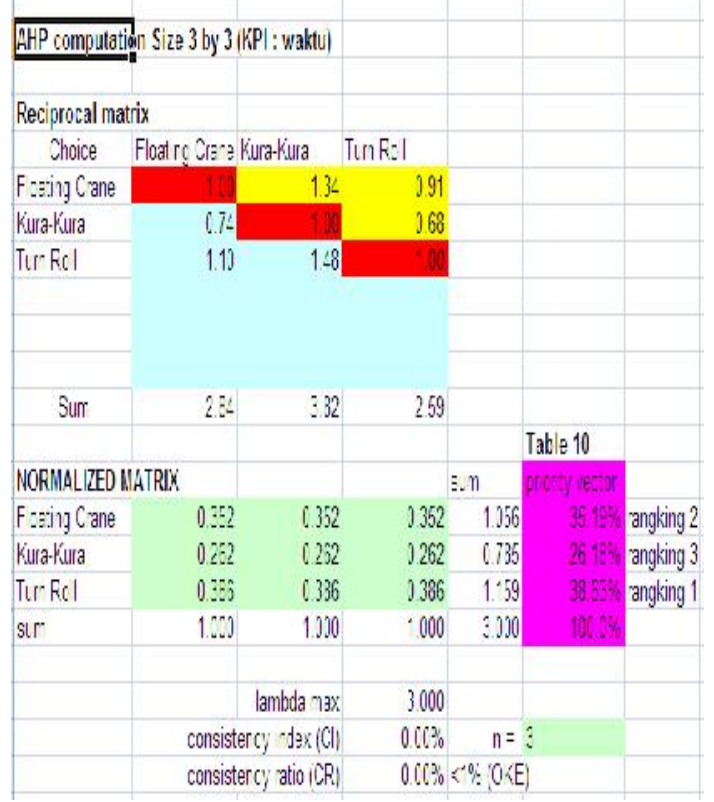

Gambar 7.

Hasil Analisis Priority Vector Masing-Masing Alternatif untuk KPI :Waktu

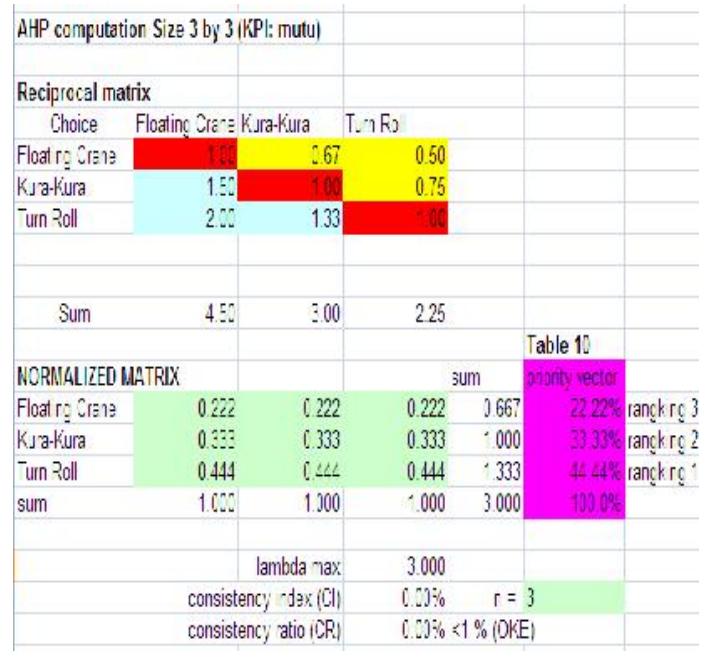

Gambar 8.

Hasil Analisis Priority Vector MasingMasing Alternatif untuk KPI :Mutu ratakan hasil Priority Vector dari masingmasing KPI maka akan diperoleh Priority Vector untuk elemen Alternatif (Floating Crane, Kura-Kura, Turn Roll) seperti pada Gambar 12.

Dengan cara analisis yang sama (analog), maka dapat diperoleh hasil analisis Priority Vector Masing-masing alternatif (Floating Crane, Kura-Kura, Tun Roll) untuk semua jenis KPI : (mutu, waktu, biaya, cara operasi, resiko) seperti pada Gambar 13.

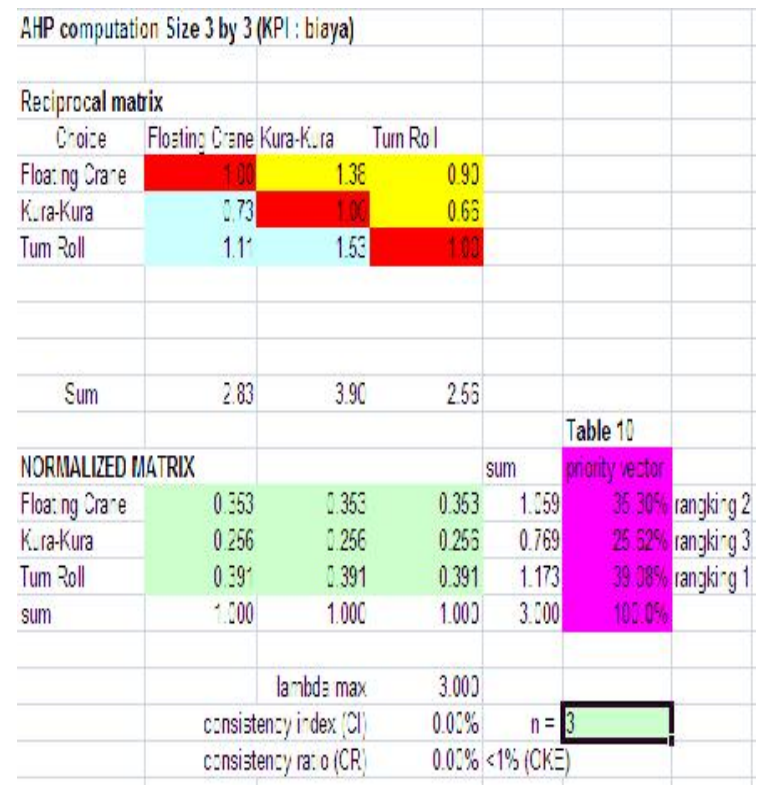

Gambar 9.

Hasil Analisis Priority Vector MasingMasing Alternatif untuk KPI: Biaya

AHP computation Size 3 by 3 |KF| : cora operasi $)$

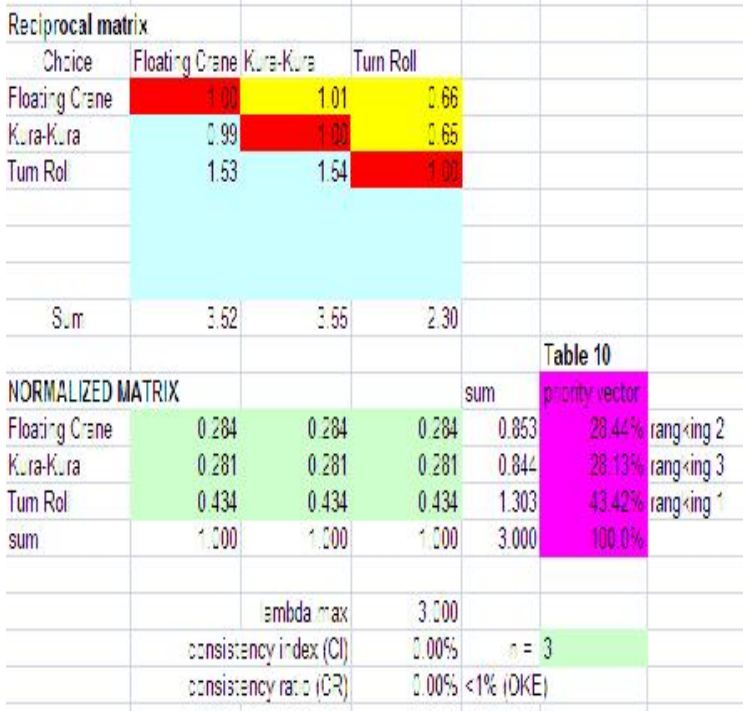

Gambar 10.

Hasil Analisis Priority Vector MasingMasing Alternatif Untuk KPI: Cara Operasi 
Penerapan Metode AHP dalam Proses Pemilihan Alat Angkut Berat pada Konstruksi Terowongan Layang Bawah Laut, (Dwi Agus Purnomo)

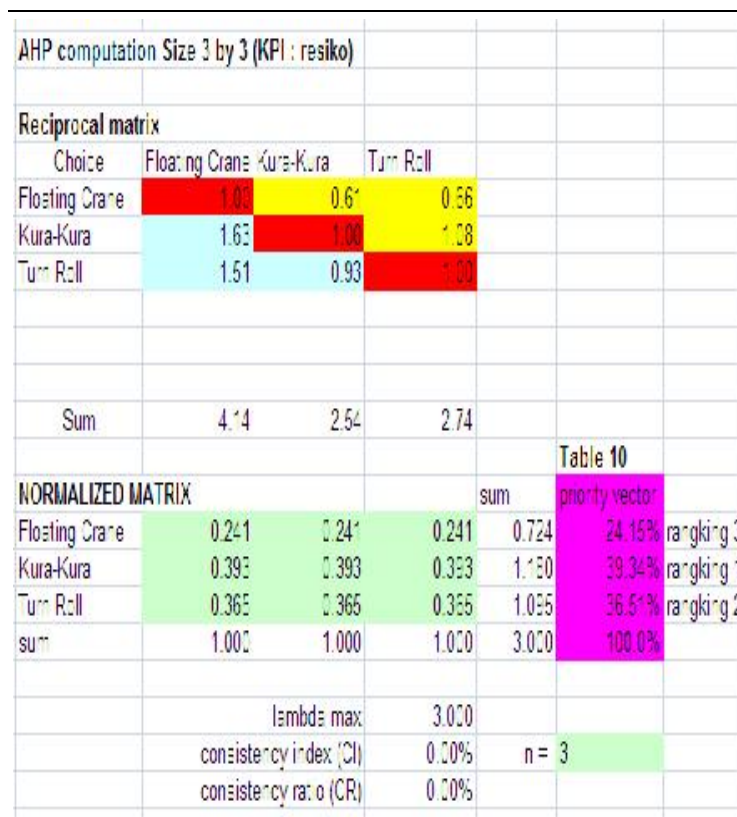

Gambar 11.

Hasil AnalisisPriority Vector MasingMasing Alternatif untuk KPI: Resiko

\begin{tabular}{|c|c|c|}
\hline \multicolumn{2}{|c|}{ RATA-RATA PRIORITY VECTOR } & prisity vector \\
\hline \multicolumn{2}{|l|}{ Flaating Grane } & $29.06 \%$ |rangking 3 \\
\hline Kura-Kura & & $30.52 \%$ |rangking 2 \\
\hline Tum Ridl & & 40.42\% rangking 1 \\
\hline & Jumlah & $100.00 \%$ \\
\hline
\end{tabular}

Gambar 12.

Hasil Analisis Priority Vector untuk elemen Alternatif

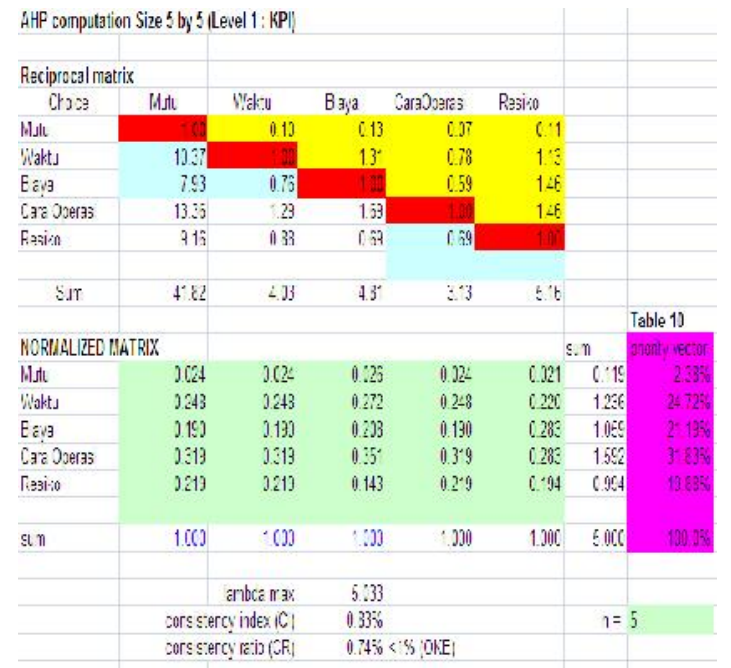

Gambar 13.

Hasil Analisis Priority Vector Untuk Level 1: semua jenis KPI (Mutu,Waktu, Biaya, Cara Operasi, Resiko)

\section{SIMPULAN}

Berdasarkan hasil sintesa atribut kriteria (Level 1 dan Level 2) dan alternatif terhadap tujuan (Level 0), maka metode Turn Roll menjadi prioritas alternatif pertama dengan bobot prioritas sebesar 0,4042. Kemudian disusul metode Kura-Kura menjadi prioritas alternatif kedua dengan bobot sebesar 0,3052 dan metode Floating Crane menjadi prioritas terakhir dengan bobot prioritas sebesar 0,2906; yang didukung dengan kelompok KPI. Prioritas utama adalah "Cara Operasi" dengan bobot prioritas 0,3183; disusul dengan KPI: "Waktu" dengan bobot prioritas 0,2472, KPI: "Biaya" dengan bobot prioritas 0,2119, KPI: "Resiko" dengan bobot prioritas 0,1988, dan KPI: "Mutu" dengan bobot prioritas 0,0238 .

Nilai bobot prioritas alternatif dari hasil sintesa antar atribut dan alternatif tersebut, maka dapat putuskan metode konstruksi dengan sistem Turn Roll dapat dipilih dalam pelaksanan pemasangan badan SFT.

\section{UCAPAN TERIMA KASIH}

Kajian dalam penelitian ini terselenggara atas pembiayaan DIPA Pusat Teknologi Industri dan Sistem Transportasi, BPPT Tahun 2012, Penyusunan Rancangan Rinci SFT.

\section{DAFTAR PUSTAKA}

1. Istimawan Dipohusodo, Manajemen Proyek dan Konstruksi, Penerbit Kanisius, Cetakan ke 7, 2006, Kotak Pos 1125/Yk, Yogyakarta 5501.

2. Djoko Wilopo, Metode Konstruksi dan Alat Berat, Penerbit UI Press, 2009, ISBN : 9789799456372.

3. Saaty TL, Multicriteria Decision Making, 1990, RWS Publication, 4922 Ellsworth Avenue, Pittsburgh, PA.

4. Kardi Technomo, Kardi Teknomo's Tutorial on Anaytic Hierarchy Process Tutorial, 2006.

5. Wulfram I. Ervanto, Manajemen Konstruksi, Andi Publisher 2006. 